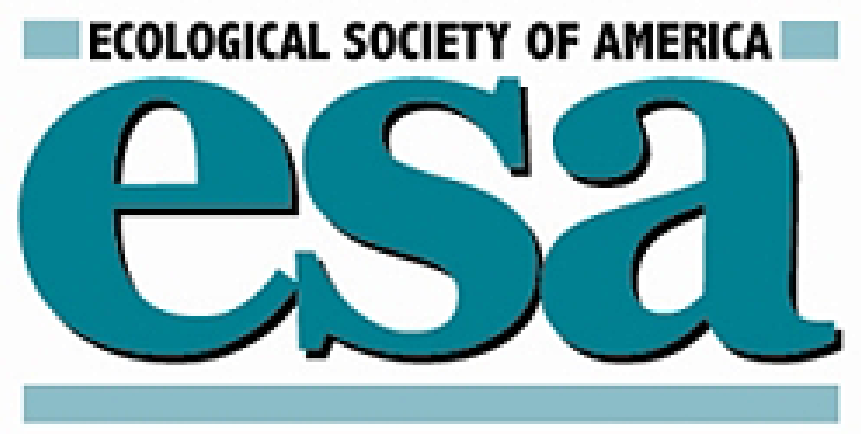

Reproductive Energetics and Prey Harvest of Leach's Storm-Petrels in the Northwest Atlantic Author(s): W. A. Montevecchi, V. L. Birt-Friesen and D. K. Cairns

Source: Ecology, Vol. 73, No. 3 (Jun., 1992), pp. 823-832

Published by: Ecological Society of America

Stable URL: http://www.jstor.org/stable/1940160

Accessed: 25/06/2013 12:28

Your use of the JSTOR archive indicates your acceptance of the Terms \& Conditions of Use, available at http://www.jstor.org/page/info/about/policies/terms.jsp

JSTOR is a not-for-profit service that helps scholars, researchers, and students discover, use, and build upon a wide range of content in a trusted digital archive. We use information technology and tools to increase productivity and facilitate new forms of scholarship. For more information about JSTOR, please contact support@ jstor.org. 


\title{
REPRODUCTIVE ENERGETICS AND PREY HARVEST OF LEACH'S STORM-PETRELS IN THE NORTHWEST ATLANTIC ${ }^{1}$
}

\author{
W. A. MONTEVECCHI AND V. L. BIRT-Friesen \\ Departments of Biology and Psychology, and Ocean Sciences Centre, Memorial University of Newfoundland, \\ St. John's, Newfoundland, Canada AIB $3 \times 9$

\section{K. CAIRNS} \\ Departments of Biology and Psychology, and Ocean Sciences Centre, Memorial University of Newfoundland, \\ St. John's, Newfoundland, Canada AIB $3 X 9$ and \\ Science Branch, Department of Fisheries and Oceans, Box 5030, Moncton, \\ New Brunswick, Canada EIC $9 B 6$
}

\begin{abstract}
Leach's Storm-Petrels (Oceanodroma leucorhoa), the smallest and most abundant seabirds that breed in the northwest Atlantic, are not usually included in avian energetics models. To round out an energy analysis of seabirds spanning the full range of body sizes in the northwest Atlantic, the field metabolic rates (FMRs) of breeding Leach's Storm-Petrels were measured using doubly labeled water techniques (DLW). Metabolic, dietary and, demographic data were used as inputs in a populations energetics model to estimate the energy requirements and prey harvests of the Leach's Storm-Petrel population of eastern North America.

FMRs of storm-petrels that remained in burrows averaged $83.3 \pm 19.4 \mathrm{~kJ} / \mathrm{d}$. FMRs increased significantly with time (i.e., $x$ in hours per day) at sea $(y=[85.8 \pm 6.5]+[3.13$ $\pm 0.48] \times$, and metabolism at sea was estimated to be $161 \pm 18 \mathrm{~kJ} / \mathrm{d}$. FMRs integrated over activity on land and activity at sea averaged $124 \mathrm{~kJ} / \mathrm{d}$ during incubation and $142 \mathrm{~kJ} / \mathrm{d}$ during chick rearing. Incubating adults weighed significantly more than adults rearing chicks, although adult mass did not vary with age of chick. Basal metabolic rate (BMR, measured as $\mathrm{O}_{2}$ flux) averaged $2.02 \pm 1.01 \mathrm{~cm}^{3} \cdot \mathrm{g}^{-1} \cdot \mathrm{h}^{-1}$, equivalent to $45.4 \pm 30.4 \mathrm{~kJ} / \mathrm{d}$, very similar to values obtained for breeding conspecifics in the Bay of Fundy and in the Bering Sea. Thermal conductance averaged $0.124 \pm 0.065 \mathrm{~cm}^{3} \cdot \mathrm{g}^{-1} \cdot \mathrm{h}^{-1} \cdot{ }^{\circ} \mathrm{C}^{-1}$. FMR/BMR ratios averaged 2.73 for incubating birds and 3.13 for birds rearing young. Population energetics modelling indicated that during a 7-mo breeding period Leach's Storm-Petrels at colonies in the northwest Atlantic Ocean consume $>74000 \mathrm{Mg}$ of prey, mostly myctophids and amphipods (mostly Hyperia galba), as well as euphausiids (mostly Meganyctiphanes norvegica) and other prey (decapods, copepods, isopods). Leach's Storm-Petrels make up $\approx 80 \%$ of the breeding seabird population in eastern Canada, but owing to small body size and metabolic efficiency, they account for comparatively little of the energy that flows through the avian assemblage of the northwest Atlantic.

An intra-specific, inter-colony difference in FMR is suggested: FMRs measured in a Newfoundland colony were significantly higher than those determined with the same DLW procedure in the Bay of Fundy near the southern limit of the species' breeding range in the northwest Atlantic. Differences in ambient temperatures and wind speed associated with different oceanographic regimes may generate energetic differences. Like inter-colony differences in feeding ecology, inter-colony differences in FMR need to be considered in population and community energetics models and in meso- and mega-scale extrapolations.

Key words: biological oceanography; doubly labeled water; field metabolic rate (FMR); food webs; inter-colony differences; northwest Atlantic Ocean; population energetics; population energetics model; prey consumption; seabird oceanography; storm-petrels; trophic interactions.
\end{abstract}

\section{INTRODUCTION}

Birds are highly visible, wide-ranging, easily studied apex predators in marine food webs. Population energetics models indicate that they consume substantial amounts of marine prey (Furness 1982, Weins 1984).

' Manuscript received 26 February 1990; revised 20 March 1991; accepted 26 June 1991; final version received 12 August 1991.
Doubly labeled water (DLW) techniques have been used to determine the energy expenditures of two ecologically important avian species occupying different trophic levels in the northwest Atlantic. Both Northern Gannets (Sula bassana, large aerial foragers that feed primarily on large pelagic fish and squid) and Common Murres (Uria aalge, pursuit divers that feed primarily on capelin, Mallotus villosus) showed field metabolic rates $($ FMRs) $\approx 50 \%$ higher than allometric extrapo- 
lations for high-latitude seabirds (Ellis 1984, Birt-Friesen et al. 1989, Cairns et al. 1990). These high energy turnovers were considered to be due in part to thermoregulatory demands imposed by a cold ocean environment and to costly (flapping-flight) foraging modes.

Planktivorous Leach's Storm-Petrels (Oceanodroma leucorhoa), the smallest and most abundant seabirds that breed in the northwest Atlantic (Brown et al. 1975 , Cairns et al. 1989), are usually not included in energetics models involving marine birds (Sklepkovych and Montevecchi 1989; cf. Cairns et al. 1991). To complete the energetic analysis of the full body-size spectrum of marine birds in the northwest Atlantic, we used DLW to measure the FMRs of breeding Leach's Storm-Petrels in a cold oceanic region fed by the Labrador Current (Newfoundland). As with larger seabirds, oceanographic influences in Newfoundland waters were expected to produce higher metabolic demands (BirtFriesen et al. 1989), which might be similar to those experienced by storm-petrels in the Antarctic (Obst et al. 1987). To date, FMR findings from DLW studies have been treated mainly as species-specific and broadly generalizable. Recent reports have indicated, however, that FMRs may vary among colonies and years (e.g., Gales and Green 1990). The present study compared the FMRs obtained with DLW of Leach's StormPetrels breeding in Newfoundland with those in the Bay of Fundy (Ricklefs et al. 1986). Metabolic, dietary, and demographic data were used in a population energetics model to estimate the species' energy requirements and prey harvest in the northwest Atlantic. Results are compared with those of larger avian species feeding at higher trophic levels (Birt-Friesen et al. 1989, Cairns et al. 1990).

\section{METHODS}

\section{Doubly labeled water}

Field metabolic rates (FMRs) of breeding adult Leach's Storm-Petrels were measured with doubly labeled water (DLW) during July 1987 on Green Island $\left(46^{\circ} 53^{\prime} \mathrm{N}, 56^{\circ} 05^{\prime} \mathrm{W}\right.$, Newfoundland) where the species' breeding population is estimated as 72000 pairs (Cairns et al. 1989). Subjects were captured in nest burrows during the day, weighed (100-g Pesola spring scale) and injected pectorally with $0.15 \mathrm{~mL}{ }^{3} \mathrm{HH}^{18} \mathrm{O}$ containing 95 atom $\%{ }^{18} \mathrm{O}$ (i.e., oxygen in which $95 \%$ of the atoms were ${ }^{18} \mathrm{O}$ ) and ${ }^{3} \mathrm{H}$ whose disintegration rate was $46 \mathrm{kBq} / \mathrm{mL}$. They were then banded with United States Fish and Wildlife Service bands and returned to burrows. Grass lattices were laid over burrow entrances and were checked at 15-min intervals through the next three nights. When a lattice either had been disturbed or had not been disturbed for $24 \mathrm{~h}$ or longer since injection, we examined the burrow. If an injected animal was recovered, $\approx 0.2-0.6 \mathrm{~mL}$ of blood was drawn from a brachial vein, and the bird was weighed and returned to its burrow. Of the 20 storm-petrels that were injected with DLW and recaptured, 8 did not leave the burrow from the time of injection until recapture ( 7 of these animals were incubating, 1 was with a chick). Twelve others spent from 8.6 to $21.0 \mathrm{~h} / \mathrm{d}$ at sea between injection and recapture (10 of these birds were rearing chicks, 2 were incubating). Following Ricklefs et al.'s (1986) procedure, initial isotope levels were determined from measurements for nine animals that were injected with ${ }^{3} \mathrm{HH}^{18} \mathrm{O}$, returned to burrows for $\mathrm{l} \mathrm{h}$, then bled. Initial isotope values for these animals were regressed on body mass; initial isotope levels for 17 storm-petrels, for which initial blood samples were not obtained, were estimated from body mass using this regression equation. Three of the nine birds were recaptured within $2 \mathrm{~d}$, and FMR and water-turnover calculations for these animals were based on actual initial isotope values.

Blood samples were stored frozen in airtight heparinized tubes. In the laboratory, blood was thawed and vacuum-distilled (Nagy 1983). Tritium activity was measured in duplicate or triplicate on $10-\mu \mathrm{L}$ samples of water in a Beckman LS7500 scintillation counter. ${ }^{18} \mathrm{O}$ in the remaining water from each sample was analyzed in duplicate or triplicate at Nagy's (1983) laboratory at the University of California at Los Angeles by proton activation of ${ }^{18} \mathrm{O}$ to ${ }^{18} \mathrm{~F}$ with subsequent counting of ${ }^{18} \mathrm{~F}$ in a gamma counter (Wood et al. 1975, Nagy 1980). Standards were made by diluting $100-\mu \mathrm{L}$ injection solution in $20.0 \mathrm{~mL}$ of distilled water and were analyzed in triplicate. Background isotope levels were measured on three uninjected storm-petrels.

$\mathrm{CO}_{2}$ production (in millilitres per gram per hour), water influx (in millilitres per kilogram per day) and water efflux (in millilitres per kilogram per day) were calculated for each storm-petrel for the interval between initial and final captures, assuming body water volume changed as a constant fraction of body mass (Nagy 1980, 1983, Nagy and Costa 1980). Body mass was calculated as the mean of masses at initial and final captures. Total body water was estimated from ${ }^{18} \mathrm{O}$ dilution space (Nagy 1983). FMR (in kilojoules per day) was calculated from $\mathrm{CO}_{2}$ production assuming an energy equivalent of $0.0263 \mathrm{~kJ} / \mathrm{mL}$ of $\mathrm{CO}_{2}$ for myctophids, amphipods, and euphausiids. Metabolizable energy intake (ME, in kilojoules per day) was calculated from water influx, assuming an energy assimilation efficiency of 0.80 (Ricklefs 1974) and a gross energy equivalent of $8.10 \mathrm{~kJ} / \mathrm{mL}$ of $\mathrm{H}_{2} \mathrm{O}$ for myctophids, amphipods, and euphausiids, and assuming that birds at sea did not ingest sea water (i.e., all water intake was due to preformed water in the food and metabolic water produced from the food).

\section{Estimates of hasal metabolic rate and thermal conductance}

Oxygen consumption $\left(\mathrm{VO}_{2}\right)$ was measured on seven nonlabeled breeding storm-petrels on Green Island 
(Newfoundland) and on two others on Great Island $\left(47^{\circ} 11^{\prime} \mathrm{N}, 52^{\circ} 49^{\prime} \mathrm{W}\right.$, Witless Bay Ecological Reserve, Newfoundland). Birds were removed from nest burrows during daylight, returned to a cabin and placed in 16.33- $\mathrm{L}$ plastic airtight chambers that contained a layer of soda lime and Drierite to absorb $\mathrm{CO}_{2}$ and $\mathrm{H}_{2} \mathrm{O}$, respectively, beneath plastic-mesh flooring. Birds were allowed to acclimate for $\approx 2 \mathrm{~h}$ before the chambers were sealed and connected to a Yellow Springs Instrument thermistor and a water-filled manometer. No attempts were made to control air temperatures, which were within the thermal neutral zone (Ricklefs et al. 1986). Changes in air pressure and temperature in the chambers were recorded. Atmospheric pressure changes during 15-min tests were assumed to be negligible. Only tests during which the pressure in the chamber decreased steadily and during which the bird remained quiescent were used. $\mathrm{VO}_{2}$ was estimated using Ricklefs et al.'s (1986) equation and was converted to energy turnover with a factor of $0.0201 \mathrm{~kJ} / \mathrm{mL}$ of $\mathrm{O}_{2}$. This volumetric technique of measuring $\mathrm{VO}_{2}$ is highly amenable to field situations, and though it has not been validated with open system respirometry, very similar techniques have, and the technique has produced results similar to those generated by other procedures (see Discussion) and by allometric extrapolations (BirtFriesen et al. 1989). These data were used to estimate basal metabolic rate (BMR). $\mathrm{VO}_{2}$ has not been found to vary diurnally for this species (Ricklefs et al. 1980). Although 8-14 h had passed since dawn and the last possible feeding, storm-petrels and other procellariids can retain lipids and other foods in stomachs for $\geq 1$ d after feeding (Obst et al. 1987), so birds used in our tests may not have been in a post-absorptive state.

Thermal conductances were calculated for nine 15min metabolism chamber tests run at temperatures ranging from $15.6^{\circ}$ to $24.2^{\circ} \mathrm{C}$, using the equation of Obst et al. (1987):

$$
C_{t}=\mathrm{VO}_{2} /\left(T_{b}-T_{a}\right),
$$

where $C_{t}$ is thermal conductance in $\mathrm{cm}^{3} \cdot \mathrm{g}^{-1} \cdot \mathrm{h}^{-1} \cdot{ }^{\circ} \mathrm{C}^{-1}$, $\mathrm{VO}_{2}$ is oxygen consumption in $\mathrm{cm}^{3} \cdot \mathrm{g}^{-1} \cdot \mathrm{h}^{-1}, T_{h}$ is body temperature in degrees Celsius, and $T_{a}$ is ambient air temperature in degrees Celsius.

\section{Adult body mass}

We weighed (100-g Pesola spring scale) and banded 69 adult Leach's Storm-Petrels that were removed from nest burrows on Green Island during daylight hours. Of these, 40 were incubating and 24 were with chicks.

\section{Meteorological/oceanographic comparisons}

Data on regional air temperatures and wind speeds during the study periods on Green (July 1987) and Kent (July 1983) Islands (Newfoundland and Maine, respectively) were obtained from the Canadian Environmental Service. Sea surface temperatures (SSTs) during investigation periods and within the storm-petrels' for- aging ranges were generated by averaging the proportionate areas of SSTs within blocks $4^{\circ}$ latitude by $3^{\circ}$ longitude around each of the study islands. SST charts were obtained from the Canadian Forces Meteorological and Oceanographic Centre in Halifax (Nova Scotia, Canada). General information on typical regional fog conditions was obtained from Steele et al. (1979).

\section{Food sampling}

As DLW tests were being conducted, parental food samples were collected by mist-netting adults returning to the colony at night. Plastic tarps laid under mist nets collected regurgitations from netted birds on Green Island and on Gull Island $\left(47^{\circ} 16^{\prime} \mathrm{N}, 52^{\circ} 46^{\prime} \mathrm{W}\right)$ in Witless Bay $(N=800)$. Samples were either frozen or stored in a solution of $5 \%$ formalin. Seven fresh samples were dried and analyzed for protein, lipid, and ash at the Fish Inspection Laboratory, Fisheries and Oceans Canada, in St. John's. Data were used to calculate the energy contents of parental feeds (methods in Montevecchi and Piatt 1984).

\section{Statistics}

Data were independent and approximately normally distributed (Komogorov-Smirnov test; $P>.05$ ), so parametric statistics were used throughout. Level of significance is taken as .05 . Means are given \pm 1 standard deviation (SD), and regression values \pm 1 standard error (SE); $t$ tests are two-tailed unless otherwise stated.

\section{Population energetics model}

Following the design structure of Furness (1978) and Wiens (1984), a population energetics model of prey consumption was developed on VP Planner, a Lotus 1-2-3 compatible spreadsheet. Estimates of energy use by individual adults form the core of the model, and other calculations were used to account for costs of reproduction. FMRs determined in the present study were used in the model, except for storm-petrels breeding in Nova Scotia and New Brunswick, for which Ricklefs et al.'s (1986) value was used. Input parameters, which are detailed below (Table 4), were integrated at the population level. Energy densities of parental feeds and of prey species and the percentages that different prey represented in the total mass of the diet were then used to estimate the total masses of different prey consumed during the storm-petrels breeding season (see Montevecchi et al. 1987). Details of the model are presented in Cairns et al. (1991).

\section{RESULTS}

\section{Body masses, metabolic rates, and thermal conductances}

Adults with eggs in their nest burrows weighed significantly more than adults rearing chicks (Table 1). Masses of adults with small chicks $(<20 \mathrm{~g})$ were not significantly different from those of adults with large 
TABLE 1. Masses of adult Leach's Storm-Petrels with eggs, chicks, and chicks of different masses (ages) in their nest burrows (means $\pm 1 \mathrm{SD}$ ) and correspondent one-way ANOVA.

\begin{tabular}{ccccccc}
\hline \hline \multicolumn{3}{c}{ Adult mass $(\mathrm{g})$} & & & \\
\cline { 1 - 3 } Egg stage & $\begin{array}{c}\text { Chick stage } \\
(<20 \mathrm{~g})\end{array}$ & & & & \\
\cline { 2 - 6 } & $(>20 \mathrm{~g})$ & $F$ & $\mathrm{df}$ & $P$ \\
\hline $47.7 \pm 4.7$ & $45.2 \pm 3.4$ & 4.83 & 1,62 & $<.05$ \\
& $46.4 \pm 3.5$ & $44.9 \pm 3.4$ & 0.81 & 1,16 & $>.05$ \\
\hline
\end{tabular}

chicks ( $>20 \mathrm{~g}$; Table 1$)$; the correlation between chick and parental masses was also nonsignificant $(r ; P>$ $.05)$.

Background oxygen isotopic values averaged 0.2019 $\pm 0.0001 \%{ }^{18} \mathrm{O}$. We checked for systematic error in estimates of $\mathrm{CO}_{2}$ production as final ${ }^{18} \mathrm{O}$ levels in labeled birds approached background levels in two ways. (1) Maximum difference in ${ }^{18} \mathrm{O}$ measurements from replicate analyses of five samples (including re-distillations) was $3.5 \%$. Final ${ }^{18} \mathrm{O}$ measurements for all birds were $>0.0085$ atom $\%$ excess (above background), which is $4.2 \%$ of background and outside the range of maximum differences for replicate ${ }^{18} \mathrm{O}$ analyses (BirtFriesen et al. 1989). (2) We plotted $\mathrm{CO}_{2}$ production against final ${ }^{18} \mathrm{O}$ measurements. The plot yielded no evidence of systematic bias. We therefore included all data points in subsequent analyses.

The field metabolic rates (FMRs) of eight stormpetrels that remained in nest burrows averaged $83.3 \pm$ $19.4 \mathrm{~kJ} / \mathrm{d}$ (Table 2). Adults that spent all or part of their time at sea had significantly higher FMRs than did adults that remained in nest burrows (Table 3; $t=$ $-6.7 ; N=20 ; P<.001)$. FMR increased significantly with time spent at sea according to the linear relationship

$$
y=(85.8 \pm 6.5)+(3.13 \pm 0.48) x,
$$

where $y$ is FMR in kilojoules per day and $x$ is time at sea in hours per day $(r=0.84 ; P<.001$; see Fig. 1$)$. The intercept of the regression $(85.8 \pm 6.5 \mathrm{~kJ} / \mathrm{d}$ or 3.58 $\pm 0.27 \mathrm{~kJ} / \mathrm{h}$ ) is the predicted metabolic rate of a bird in the nest burrow and is not significantly different from the direct measurements on birds that remained in nest burrows $(t$ test; $P>.05)$. The regression slope (3.13 \pm $0.48 \mathrm{~kJ} / \mathrm{h}$ ) is the incremental cost of being at sea over maintenance costs. Assuming that the incremental cost of being at sea is additive to metabolism in the nest burrow, then total metabolism at sea is estimated to be $6.71 \pm 0.75 \mathrm{~kJ} / \mathrm{h}$ or $16 \mathrm{l} \pm 18.0 \mathrm{~kJ} / \mathrm{d}$. Metabolism at sea can also be estimated by subtracting estimated energy expended at the nest site from total energy expenditure for each storm-petrel that went to sea. This procedure yields a mean estimate of metabolism at sea of $168 \pm 33 \mathrm{~kJ} / \mathrm{d}$. Estimates of metabolic rates calculated by these methods were not significantly different ( $t$ test; $P>$.05). Metabolic rates at sea calculated by subtraction did not vary with time at sea. Neither FMRs nor metabolic rates at sea correlated with chick wing length (age).

On average, storm-petrels that remained at the nest burrow lost mass between captures (one-tailed $t$ test; $t$ $=-3.58 ; N=12 ; P<.01$; Table 2). Birds that went to sea did not change in mass and remained in energy balance ( $t$ test; Table 3 ). Metabolizable energy intake (ME) was positively correlated with time spent at sea $(r=0.61 ; N=12 ; P<.05)$ according to the equation

$$
y=(48.8 \pm 48.0)+(6.62 \pm 2.73) x,
$$

where $y$ is $\mathrm{ME}$ in kilojoules per day and $x$ is time at sea in hours per day. Energy balance (ME - FMR) and change in mass of birds that went to sea were not correlated with time spent at sea.

Whole-animal FMR was significantly correlated with body mass for birds that went to sea $(y=[-6.4 \pm$ $56.2]+[3.23 \pm 1.23] x ; r=0.64 ; N=12 ; P<.05)$, but not for those that remained in nest burrows. Stormpetrels that are incubating eggs or brooding small chicks spend $\approx 50 \%$ of their time at the nest burrow and $\approx 50 \%$ at sea (Ricklefs et al. 1986). Those with larger chicks spend at least three times as much time at sea as the nest-burrows (W. A. Montevecchi and V.L. Birt-Friesen, personal observations). As our FMR measurements do not represent complete at-sea and at-land activity cycles, we integrated FMR over sufficient intervals to include full activity cycles (Obst et al. 1987). Integrated FMRs averaged $124 \mathrm{~kJ} / \mathrm{d}$ during incubation/brooding and $142 \mathrm{~kJ} / \mathrm{d}$ during chick-rearing.

Mass-specific BMR (as $\mathrm{O}_{2}$ consumption rate) averaged $2.02 \pm 1.01 \mathrm{~cm}^{3} \mathrm{~g}^{-1} \cdot \mathrm{h}^{-1}\left(94.1 \pm 47.1 \mathrm{~cm}^{3} / \mathrm{h}\right)$, equivalent to $2.07 \pm 1.27 \mathrm{~kJ} / \mathrm{h}(45.4 \pm 30.4 \mathrm{~kJ} / \mathrm{d})$. Thermal conductance averaged $0.124 \pm 0.065 \mathrm{~cm}^{3}$. $\mathrm{g}^{-1} \cdot \mathrm{h}^{-1 \cdot{ }^{\circ}} \mathrm{C}^{-1}$.

\begin{tabular}{|c|c|c|c|c|}
\hline Measurement & $\bar{X}$ & SD & Min. & Max. \\
\hline Body mass $(\mathrm{g})$ & 47.5 & 4.3 & 41.7 & 55.4 \\
\hline Change in mass $(\mathrm{g} / \mathrm{d})$ & -9.0 & 7.1 & -19.8 & -0.2 \\
\hline Recapture interval (d) & 1.26 & 0.38 & 1.06 & 2.17 \\
\hline $\mathrm{CO}_{2}$ production $\left(\mathrm{mL} \cdot \mathrm{g}^{-1} \cdot \mathrm{h}^{-1}\right)$ & 2.8 & 0.7 & 1.9 & 4.2 \\
\hline Field metabolism (FMR; kJ/d) & 83.3 & 19.4 & 49.0 & 115.2 \\
\hline Water efflux $\left(\mathrm{mL} \cdot \mathrm{kg}^{1} \cdot \mathrm{d}^{1}\right)$ & 145 & 72 & 32 & 248 \\
\hline
\end{tabular}

TABLE 2. Doubly labeled water results for eight Leach's Storm-Petrels that remained in their nest burrows during testing. 


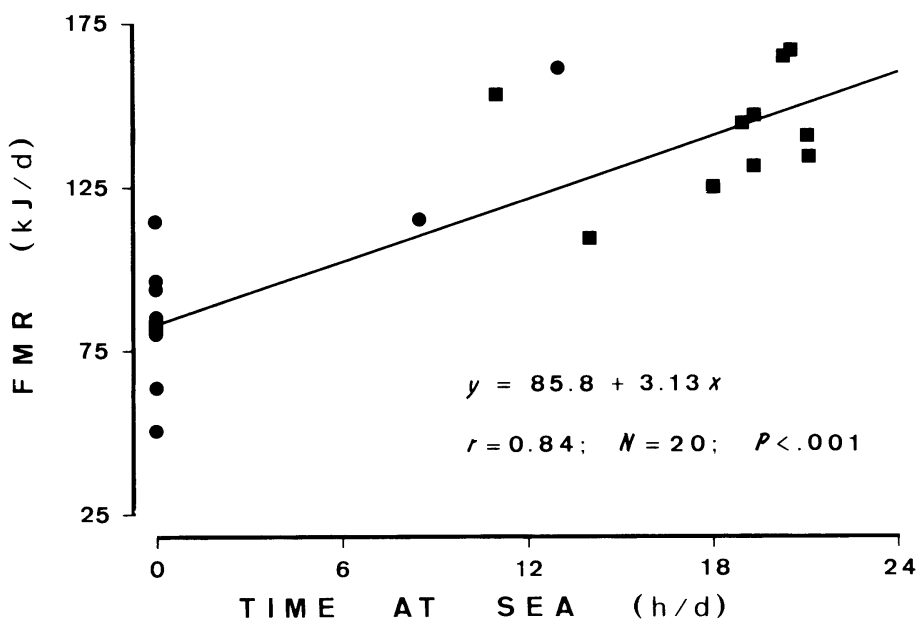

FIG. 1. Field metabolic rate (FMR) as a function of time at sea for 20 Leach's Storm-Petrels (11 of which were rearing chicks, $\mathbf{\square}$ of which had an egg, $\bullet$ ) from a colony in Newfoundland.

\section{Population energy requirements of Leach's Storm-Petrels breeding in the Northwest Atlantic}

The reproductive, nutritional, and dietary parameters that were used as input for the population energetics model are given in Tables 4,5 , and 6 . The diets of Leach's Storm-Petrels during the breeding season in Newfoundland are estimated to be comprised of (in decreasing order of mass of total food intake) myctophids, amphipods, euphausiids, and other crustaceans (Table 6). The energy densities of fresh parental food regurgitations are consistent with the energy densities of the marine food types included in them and with dietary composition in general (Table 5; Warham et al. 1976). These data and calculations of population energy requirements were used to generate coarse estimates of the masses of prey organisms that Leach's Storm-Petrels consume during their breeding season in the northwest Atlantic (Table 6). The model estimates that a breeding adult Leach's Storm-Petrel consumes $23 \mathrm{~g}$ of food per day, or $50 \%$ of body mass. Minimum total annual consumption for eastern Canada is estimated as $\approx 74000 \mathrm{Mg}$, and estimates of the harvests of major prey types are in Table 6.
The energetics model also indicated that about half of the total consumption is taken for somatic maintenance by breeding birds during the reproductive season and by non-breeders and failed breeders associated with colonies. Most of the remainder is used by young birds not attending the colony and by adults during the pre- and post-breeding periods. Only a small fraction (4.1\%) of food consumed is used directly for egg production and chick-provisioning. Much of the parental energy requirements are, however, associated with foraging for and transporting food to nestlings.

\section{DISCUSSION}

\section{Metabolic rates of Leach's Storm-Petrels}

The integrated field metabolic rates (FMRs) of Leach's Storm-Petrels breeding in Newfoundland averaged $\approx 40 \%$ higher than those of conspecifics studied with the same doubly labeled water (DLW) procedure at Kent Island, New Brunswick (Table 7; Ricklefs et al. 1986). Significant differences in mass-specific $\mathrm{CO}_{2}$ production during nest attendance and during at-sea activity were obtained between Leach's Storm-Petrels nesting in Newfoundland waters and conspecifics nesting in the Bay of Fundy (Table 8). In view of the sim-

TABLE 3. Doubly labeled water results for 12 Leach's Storm-Petrels that spent part of the time at sea.

\begin{tabular}{|c|c|c|c|c|}
\hline Measurement & $\bar{X}$ & SD & Min. & Max. \\
\hline Body mass $(\mathrm{g})$ & 45.6 & 3.6 & 41.0 & 50.7 \\
\hline Change in mass $(\mathrm{g} / \mathrm{d})$ & -1.0 & 5.4 & -9.4 & 8.4 \\
\hline Recapture interval (d) & 2.29 & 0.30 & 1.57 & 2.63 \\
\hline Percentage of time spent at sea & 70.9 & 17.8 & 36.0 & 87.0 \\
\hline $\mathrm{CO}_{2}$ production $\left(\mathrm{mL} \cdot \mathrm{g}^{-1} \cdot \mathrm{h}^{-1}\right)$ & 4.9 & 0.5 & 3.9 & 5.5 \\
\hline Field metabolism $(\mathrm{kJ} / \mathrm{d})$ & 141 & 18 & 111 & 168 \\
\hline Water intake $\left(\mathrm{mL} \cdot \mathrm{kg}^{1} \cdot \mathrm{d}^{1}\right)$ & 551 & 161 & 243 & 710 \\
\hline Water efflux $\left(\mathrm{mL} \cdot \mathrm{kg}^{-1} \cdot \mathrm{d}^{-1}\right)$ & 555 & 150 & 271 & 698 \\
\hline Metabolizable energy intake $(\mathrm{kJ} / \mathrm{d})$ & 162 & 47 & 74 & 221 \\
\hline Energy balance (ME - FMR) & 21.0 & 42.6 & -70.4 & 77.5 \\
\hline
\end{tabular}


TABLE 4. Life history parameters used in the population energetics model of prey consumption by Leach's Storm-Petrels in the northwest Atlantic. Where variability around a mean is expressed, data are mean \pm 1 SD.

\begin{tabular}{|c|c|c|}
\hline Input & Value & Sourcet \\
\hline Clutch size & 1 & 1,2 \\
\hline Hatching success & 0.67 & 3 \\
\hline Fledging success & 0.71 & 3 \\
\hline Pre-breeding period (d) & 60 & 4,5 \\
\hline Incubation (d) & 43 & 3 \\
\hline Chick period $(\mathrm{d})$ & 67 & 3,4 \\
\hline Post-breeding period $(\mathrm{d})$ & 30 & 4 \\
\hline Daily energy expenditure $\left(\mathrm{kJ} \cdot \operatorname{bird}^{1} \cdot \mathrm{d}^{-1}\right)^{*}$ & 139 & 1 \\
\hline Energy content of egg $(\mathrm{kJ})$ & $69.7 \pm 3.8$ & 6 \\
\hline Total energy for chicks (kJ) & 4988 & 7 \\
\hline Fledging mass $(\mathrm{g})$ & $56.2 \pm 5.1$ & 4 \\
\hline Northwest Atlantic breeding population (pairs) & 4512000 & 8 \\
\hline
\end{tabular}

* Based on weighted mean daily energy expenditure calculated for combined incubation and chick-rearing periods.

† Sources: (1) present study; (2) Palmer (1962); (3) R. G. Butler (unpublished data); (4) S. Bryant (unpublished data); (5) estimate by authors; (6) Montevecchi et al. (1983); (7) Ricklefs et al. (1980); (8) Cairns et al. (1989).

ilarity of basal metabolic rates (BMRs) obtained in these regions, it is unclear as to why metabolic rates in nest burrows should differ. However, as BMR tends to increase with latitute (Ellis 1984), it may be that our BMR are low (cf. Butler et al. 1986), or that BMRs in New Brunswick are lower. Further measurements of BMR could help to shed light on these differences. In comparison, the higher metabolic rates at sea in the Newfoundland region may be influenced by oceanographic and climatic factors, as well as differences in foraging ranges. Summer surface water temperatures were quite similar within the potential foraging ranges of Leach's Storm-Petrels breeding on Green $(\bar{X}=$ $\left.13.7^{\circ} \mathrm{C}\right)$ and Kent $\left(\bar{X}=13.0^{\circ} \mathrm{C}\right)$ Islands, though colder wetter, and windier conditions were associated with the Newfoundland region. Daily air temperatures in the vicinity of Green Island averaged $1.7^{\circ} \mathrm{C}$ colder than those on Kent Island during the July months when the studies were carried out, and mean annual wind speeds were $\approx 2.6 \mathrm{~km} / \mathrm{h}$ stronger at Green Island, where there was more fog (Canadian Atmospheric Environmental Service records; Steele et al. 1979).

Wind and wind chill effects may significantly elevate FMR. For instance, Black-legged Kittiwakes (Rissa tridactyla) showed significant increases in FMR during heavy winds; these were suggested to be due to increased costs of capturing prey rather than due to flight costs (Gabrielson et al. 1987; see also Kersten and

TABle 5. Percentages of organic components and energy density of fresh samples of parental food regurgitations $(n=7)$ collected from breeding adult Leach's Storm-Petrels on Green Island, Newfoundland.

\begin{tabular}{cr}
\hline \hline Component & $\bar{X} \pm 1$ SD \\
\hline Water & $72.9 \pm 2.4$ \\
Protein & $12.5 \pm 0.8$ \\
Lipid & $13.3 \pm 2.6$ \\
Ash & $1.3 \pm 0.2$ \\
$\mathrm{~kJ} / \mathrm{g}$ & $7.5 \pm 0.9$ \\
\hline
\end{tabular}

Piersma 1987, Webster and Weathers 1988, Taylor and Konarzewski 1989). These sources of energy expenditure may be interactive, as wind effects also influence prey availability via oceanographic effects (Schneider 1989). Warming cold food to body temperature could also contribute to homeothermic energy requirements in cold water regions, especially among small species like storm-petrels that consume food equivalent to about half or more of their body mass each day (Obst et al. 1987). These findings are consistent with previous DLW measurements made on larger avian piscivores in the northwest Atlantic, which were $\approx 50 \%$ higher than allometric extrapolations based on high-latitude seabirds (Ellis 1984, Birt-Friesen et al. 1989, Cairns et al. 1990). Interestingly, the energy expenditures and conductances of Leach's Storm-Petrels breeding in Newfoundland (Table 7; Obst et al. 1987) are much more similar to those of Wilson's Storm-Petrels breeding near the Antarctic Peninsula $\left(64^{\circ} 44^{\prime} S\right)$ than they are to conspecifics breeding in the Bay of Fundy.

Inter-colony, inter-annual, intra-specific differences in feeding ecology have been well documented (Schneider and Hunt 1984, Gaston and Noble 1985, Springer

TABLE 6. Estimates of total prey consumption by breeding Leach's Storm-Petrels in the northwest Atlantic.

\begin{tabular}{lcc}
\hline \hline \multicolumn{1}{c}{ Prey* } & $\begin{array}{c}\text { \% mass of total } \\
\text { food intake }\end{array}$ & Consumption $(\mathrm{Mg})$ \\
\hline Myctophids $\dagger$ & $\sim 55$ & 41400 \\
Amphipods $\ddagger$ & $\sim 30$ & 22000 \\
Euphausiids $\$$ & $\sim 10$ & 7100 \\
Other\| & $\sim 5$ & 3600 \\
Total & 100 & 74100
\end{tabular}

* W. A. Montevecchi (unpublished data) based on 800 parental food regurgitations collected on Green Island, Fortune Bay, and on Gull Island, Witless Bay, Newfoundland.

$\dagger$ Benthosema glaciale.

‡ Primarily Hyperia galba.

$\S$ Primarily Meganyctiphanes norvegica.

|| Decapods, copepods, isopods, mysids. 
TABLE 7. Metabolic rates at nest, at sea, and integrated over one at-nest/at-sea cycle of free-ranging storm-petrels rearing chicks, as determined using doubly labeled water.

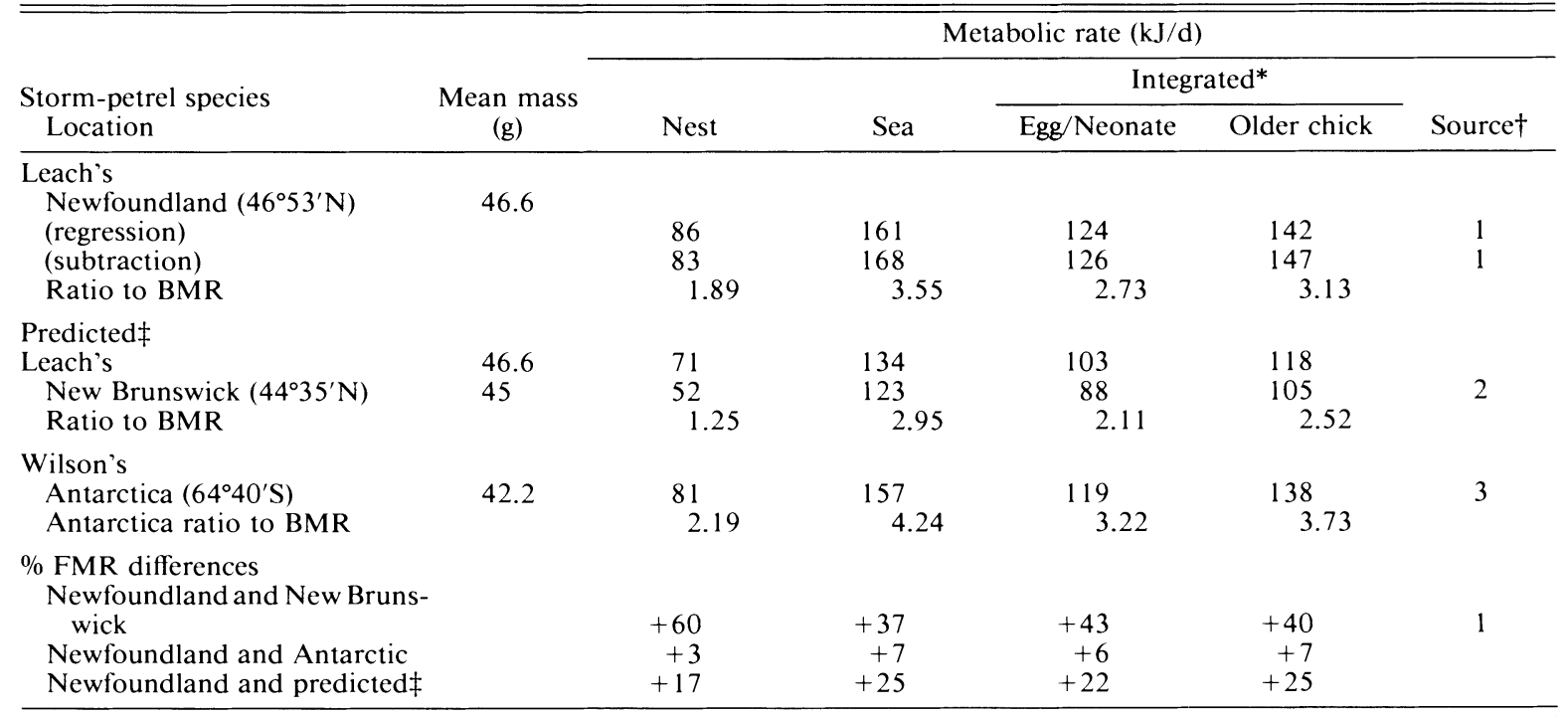

* Integrated field metabolism $=$ field metabolic rate (FMR) averaged over a sufficient period to include the full range of activities (Obst et al. 1987). Based on knowledge of life history and behavioral patterns (Table 4), metabolic rates at the nest and at sea were combined in a ratio of 1:3 to produce an integrated FMR estimate for a breeding cycle.

† Sources: (1) present study; (2) Ricklefs et al. (1986); (3) Obst et al. (1987).

$\ddagger$ Predicted by equations of Birt-Friesen et al. (1989) for a seabird occurring in a cold-water region and using predominantly gliding flight.

1991). Such differences could produce differences in FMRs at different colonies (Green and Gales 1990), particularly among those in different oceanographic regions, as well as differences at the same colony in different years (Gales and Green 1990). Differences in diet (Linton 1979; W. A. Montevecchi, unpublished data) and differences in food availability around colonies in Newfoundland and in the Bay of Fundy could produce differences in FMR. Telemetric activity recorders (e.g., Kooyman et al. 1982, Wanless et al. 1985, Cairns et al. 1987) could be used to compare foraging ranges and feeding patterns among colonies in different oceanographic regions.

Estimates of the BMR of breeding Leach's StormPetrels are similar in Newfoundland (present study; Butler et al. 1986), the Bay of Fundy (Ricklefs et al. 1986), and the Bering Sea (Iverson and Krog 1972). These estimates are within 10\% of allometric predic- tions for seabirds (Ellis 1984). The BMRs of Wilson's Storm-Petrels were $\approx 25 \%$ greater than allometric extrapolations (Obst et al. 1987). High BMRs are associated with seabirds breeding at high latitudes (Ellis 1984) and in open, wind-swept environments (Kersten and Piersma 1987; see also Adams and Brown 1984).

Lipid metabolism and mass loss are common among seabirds during incubation and reproduction (Ricklefs 1974, Adams 1990), and negative energy balances have been found in many DLW investigations of marine birds (Birt-Friesen et al. 1989). Results on mass change and energy balance (ME - FMR) indicate that stormpetrels in the present study lost mass while in the nest burrow, presumably due to consumption of reserves, but were in energy balance while at sea (see also Obst et al. 1987). Significant increases in metabolic energy intake with increasing time at sea suggest that food consumption was related to time at sea. By simulta-

TABLE 8. Comparison of the mass-specific metabolic rates (as $\mathrm{CO}_{2}$ release, means \pm 1 SE) at the nest and at sea of Leach's Storm-Petrels nesting in Newfoundland and in New Brunswick. New Brunswick data provided by R. E. Ricklefs.

\begin{tabular}{lcc}
\hline \hline \multicolumn{1}{c}{ Colony location } & \multicolumn{2}{c}{$\begin{array}{c}\text { Metabolic rate } \\
\left(\mathrm{mL} \cdot \mathrm{g}^{-1} \cdot \mathrm{h}^{-1}\right)\end{array}$} \\
\cline { 2 - 3 } & Nest & Sea \\
\hline Green Island, Newfoundland $\left(46^{\circ} 53^{\prime} \mathrm{N}\right)$ & $2.73+0.25$ & $5.08+0.11$ \\
Kent Island, New Brunswick $\left(44^{\circ} 35^{\prime} \mathrm{N}\right)$ & $1.71+0.10$ & $4.46+0.17$ \\
$t$ test & -4.37 & -3.18 \\
df & 18 & 10 \\
$P$ & $<.001$ & $<.01$ \\
\hline
\end{tabular}


neously solving Eqs. 1 and 2 for time at sea $(x)$, we can estimate that for a storm-petrel to meet its own energy requirements (i.e., for $\mathrm{ME}=\mathrm{FMR}$ ), a stormpetrel must be at sea for $\approx 10.6 \mathrm{~h} / \mathrm{d}$. Energy acquired in excess of daily needs while at sea can be used either for self maintenance during incubation/brooding or for provisioning young. A storm-petrel that remains at sea for $24 \mathrm{~h}$ could potentially acquire an excess of $47 \mathrm{~kJ} /$ d. In comparison, incubation or brooding requires 83 $\mathrm{kJ} / \mathrm{d}$, leaving a deficit of $36 \mathrm{~kJ} / \mathrm{d}$, which may explain the decrease in mass among adults with eggs compared to those with chicks (cf. Obst et al. 1987). Reduced body mass may benefit aerially foraging parents by lowering hunting and food transportation costs (cf. Norberg 1981, Schaffner 1990).

Ricklefs et al. (1980) estimated that a Leach's StormPetrel chick requires 45-50 kJ/d ME during the first 5 $\mathrm{d}$ after hatching. Assuming that each parent supplies half of this energy, then a parent with a small chick must forage for about $17-18 \mathrm{~h} / \mathrm{d}$. Time at sea includes time foraging, time travelling between the colony and feeding grounds, and time resting; storm-petrels with small chicks may spend the remaining $6-7 \mathrm{~h} / \mathrm{d}$ resting away from the nest or tending the chick. Ricklefs et al. (1980) estimated that the energy requirements of Leach's Storm-Petrel chicks asymptote at 90-100 kJ/d between 30 and $60 \mathrm{~d}$ post-hatch. A parent with a large chick must therefore either increase its foraging efficiency or effort (increase the amount of time foraging) or utilize its own reserves (see also Gales and Green 1990). We have no data on the metabolic rates of birds with larger chicks, and so unfortunately cannot address this question. Prey availability probably changes over the course of the birds' breeding season, though this issue needs to be studied. ME and water-flux calculations are based on several assumptions, and differences between ME and FMR may result in part from errors in these (Nagy 1980, Nagy and Costa 1980, Birt-Friesen et al. 1989).

The ratio of integrated $\mathrm{FMR} / \mathrm{BMR}$ is 2.73 for incubating storm-petrels and 3.13 for those rearing chicks in Newfoundland. These ratios are $\approx 25-30 \%$ higher than those of conspecifics breeding near the southern limit of their range in the northwest Atlantic. Obst et al. (1987) reported higher ratios for Wilson's StormPetrels that were incubating (3.2) and rearing thermally independent young in the Antarctic (3.73; Table 7). Most seabird species exhibit rates of energy utilization similar to those of most other avian species, i.e., 3-4 $\times$ BMR (Drent and Daan 1980, Birt-Friesen et al. 1989). In view of the small body size, pelagic foraging patterns, and high-latitude distributions of storm-petrels, these energetic similarities indicate that stormpetrels are well adapted to cold ocean environments (Obst et al. 1987). This suggestion is supported by findings that (1) FMR/BMR ratios of storm-petrels rearing chicks were much lower than those of Northern Gannets (6.6) or Common Murres (5.2); and (2) storm- petrels did not exhibit higher mass-specific BMRs than the larger species, indicating that like other Procellariiformes, they are metabolically conservative (Rahn and Whittow 1984, Adams et al. 1986). Suggestions of such energy efficiency, however, contrast with previous demonstrations of Leach's Storm-Petrel's inability to rear artificially enlarged broods of two chicks (Huntington 1963; see also Birt-Friesen et al. 1989). The species' reproductive output may be constrained by longer term life-history patterns that may not be detectable in single-season energetics studies of a longlived organism (Stearns 1977).

Metabolism at sea is similar for Wilson's StormPetrels (Obst et al. 1987) and Leach's Storm-Petrels. The former species very rarely alights on the water while foraging at sea (Obst et al. 1987), whereas the latter species alights on the water at night (W. A. Montevecchi, personal observation) and may do so for long periods (Ricklefs et al. 1986). Storm-petrels, like gannets (Birt-Friesen et al. 1989) and other species whose wings have high aspect ratios (Flint and Nagy 1984), have evolved very energy-efficient flight patterns that are linked to pelagic foraging (Obst et al. 1987; present study).

\section{Population energy requirements of Leach's Storm-Petrels}

Leach's Storm-Petrels, the most abundant seabirds breeding in the northwest Atlantic (Sklepkovych and Montevechi 1989), comprise $\approx 80 \%$ of eastern Canada's breeding seabird population. Nevertheless their trophic role is relatively minor, as they consume only about $10 \%$ of the $\approx 600000 \mathrm{Mg}$ of prey taken annually by breeding seabirds in the region (Cairns et al. 1986). This modest role is due to small body size and a massspecific FMR that is low in comparison with other members of the eastern Canadian breeding seabird assemblage. The influence of these factors can be illustrated by a comparison with the Common Murre. Leach's Storm-Petrels, with $4.5 \times 10^{6}$ breeding pairs, has a biomass of $555 \mathrm{Mg}$, whereas the region's Common Murre population $\left(570 \times 10^{3}\right.$ breeding pairs $)$ has a biomass of $1441 \mathrm{Mg}$. Overall consumption by Common Murres $(330000 \mathrm{Mg})$ is about five times as great as that by storm-petrels $(\approx 74000 \mathrm{Mg})$. However, it is important to consider that the smaller nekton-consuming seabird species can potentially remove many more larval and juvenile fish compared to larger avian piscivores that prey on larger fish.

For the most part, marine population and community energetics models tend to treat FMR measurements as species-typical, and oceanography as widely generalizable. The findings that FMRs vary among colonies and may vary between years at the same colony (e.g., Gales and Green 1990) indicate the necessity of considering such differences in population and community energetics models that involve large oceanographic regions and/or multiple-year inclusions. 


\section{ACKNOWLEDGMENTS}

We thank K. A. Nagy for editorial advice and assistance, R. E. Ricklefs for access to DLW data from Leach's StormPetrels on Kent Island, R. G. Butler for unpublished data on their reproductive patterns, G. Herzberg, J. Orr, and W. S. Davidson for laboratory facilities, S. Bryant and D. Butler for field assistance, G. Murphy for laboratory assistance, J. F. Amirault for meteorological information and data, and J. P. Croxall for information on myctophid energy densities. K. A. Nagy, R. P. Gales, and two anonymous reviewers provided valuable comments on earlier versions of this paper. Funding was provided by a Natural Sciences and Engineering Research Council (NSERC) of Canada Individual Operating Grant No. A0687 (to W. A. Montevecchi), a Newfoundland and Labrador Career Development Award (to W. A. Montevecchi), and NSERC Post-Graduate Scholarship (V. L. Birt-Friesen) and subventions from Fisheries and Oceans Canada (to D. K. Cairns and W. A. Montevecchi)

\section{Literature Cited}

Adams, N. J. 1990. Feeding biology and energetics of King Aptenodvtes patagonicus and Gentoo Pygoscelis papua Penguins. Dissertation. University of Cape Town, Rondebosch, South Africa.

Adams, N. J., and C. R. Brown. 1984. Metabolic rates of sub-Antarctic Procellariiformes: a comparative study. Comparative Biology and Physiology 77A:169-173

$\rightarrow$ Adams, N. J., C. R. Brown, and K. A. Nagy. 1986. Energy expenditure of free-ranging Wandering Albatrosses Diomedea exulans. Physiological Zoology 59:583-591.

Birt-Friesen, V. L., W. A. Montevecchi, D. K. Cairns, and S. A. Macko. 1989. Activity-specific metabolic rates of freeliving Northern Gannets and other seabirds. Ecology 70: 357-367.

Brown, R. G. B., D. N. Nettleship, P. Germain, C. E. Tull, and T. Davis. 1975. Atlas of Eastern Canadian seabirds. Canadian Wildlife Service, Ottawa, Ontario, Canada.

Butler, R. G., D. B. Peakall, F. A. Leighton, J. Borthwick, and R. S. Harmon. 1986. Effects of crude oil exposure on standard metabolic rate of Leach's Storm-Petrel. Condor 88:248-249.

Cairns, D. K., K. Bredin, and W. A. Montevecchi. 1987. The foraging ranges of breeding Common Murres. Auk 104: $218-224$.

Cairns, D. K., G. Chapdelaine, and W. A. Montevecchi. 1991 Prey exploitation by seabirds in the Gulf of St. Lawrence. Pages 277-291 in J. C. Therriault, editor. The Gulf of St. Lawrence: small ocean or big estuary? Canadian Special Publication of Fisheries and Aquatic Sciences 113.

Cairns, D. K., W. A. Montevecchi, and V. L. Birt. 1986 Energetics and prey consumption by seabirds breeding in Newfoundland. Pacific Seabird Group Bulletin 13:102.

Cairns, D. K., W. A. Montevecchi, V. L. Birt, and S. A. Macko. 1990. Energy expenditures, activity budgets, and prey harvests of breeding Common Murres. Avian Biology 14:84-92.

Cairns, D. K., W. A. Montevecchi, and W. Threlfall. 1989. Researcher's guide to Newfoundland seabird colonies. Second edition. Memorial University of Newfoundland Occasional Papers in Biology 14.

Drent, R. H., and S. Daan. 1980. The prudent parent: energetic adjustments in avian breeding. Ardea 6:225-252.

Ellis, H. I. 1984. Energetics of free-ranging seabirds. Pages 203-224 in G. C. Whittow and H. Rahn, editors. Seabird energetics. Plenum, New York, New York, USA.

Flint, E. N., and K. A. Nagy. 1984. Flight energetics of freeliving Sooty Terns. Auk 101:288-294.

Furness, R. W. 1982. Competition between fisheries and seabird communities. Advances in Marine Biology 20:225307.
Gabrielson, G. W., F. Mehlum, and K. A. Nagy. 1987. Daily energy expenditure and energy utilization of free-ranging Black-legged Kittiwakes. Condor 89:126-132.

Gales, R. P., and B. Green. 1990. The annual energetics cycle of Little Penguins (Eudyptula minor). Ecology 71: 2297-2312.

Gaston, A. J., and D. G. Noble. 1985. The diet of Thickbilled Murres (Uria lomvia) in West Hudson Strait and northeast Hudson Bay. Canadian Journal of Zoology 63: $1148-1160$.

Green, B., and R. P. Gales. 1990. Water, sodium and energy turnover in free-living penguins: a review. Pages 245-268 in L. David and J. Darby, editors. Penguin biology. Academic Press, New York, New York, USA.

Huntington, C. E. 1963. Population dynamics of Leach's Petrel, Oceanodroma leucorhoa. Proceedings International Ornithological Congress XIII:701-705.

Iverson, J. A., and J. Krog. 1972. Body temperatures and resting metabolic rates in small petrels. Norwegian Journal of Zoology 20:141-144.

Kersten, M., and T. Piersma. 1987. High levels of energy expenditure in shorebirds; metabolic adaptations to an energetically expensive way of life. Ardea 75:175-187.

Kooyman, G. L., R. W. Davis, J. P. Croxall, and D. P. Costa. 1982. Diving depths and energy requirements of King Penguin. Science 217:726-729.

Linton, A. 1979. The food and feeding habits of Leach's Storm-Petrel (Oceanodroma leucorhoa) at Pearl Island, Nova Scotia, and Middle Lawn Island, Newfoundland. Thesis. Dalhousie University, Halifax, Nova Scotia, Canada.

Montevecchi, W. A., V. L. Birt-Friesen, and D. K. Cairns. 1987. Dietary changes of seabirds associated with local fisheries failures. Biological Oceanography 5:153-159.

Montevecchi, W. A., I. R. Kirkham, D. D. Roby, and K. Brink. 1983. Size, organic composition and energy content of Leach's Storm-Petrel eggs with relation to position in the precocial-altricial spectrum. Canadian Journal of Zoology 61:1457-1465.

Montevecchi, W. A., and J. F. Piatt. 1984. Composition and energy contents of mature inshore spawning capelin (Mallotus villosus): implications for seabird predators. Comparative Biochemistry and Physiology 78A:15-20.

Nagy, K. A. 1980. CO production in animals: analysis of potential errors in the doubly labeled water method. American Journal of Physiology 238:R466-473.

1983. The doubly labeled water $\left({ }^{3} \mathrm{HH}^{18} \mathrm{O}\right)$ method: a guide to its use. Publication Number 12-417. University of California at Los Angeles, Los Angeles, California, USA.

Nagy, K. A., and D. P. Costa. 1980. Water flux in animals: analysis of potential errors in the tritiated water method. American Journal of Physiology 238:R454-465.

Norberg, R. A. 1981. Temporary weight decrease in breeding birds may result in more fledged young. American Naturalist 118:838-850.

Obst, B. S., K. A. Nagy, and R. E. Ricklefs. 1987. Energy utilization by Wilson's Storm-Petrel (Oceanites oceanicus). Physiological Zoology 60:200-210.

Palmer, R. S. 1962. Handbook of birds in North America. Volume 1. Yale University Press, New Haven, Connecticut, USA.

Rahn, H., and G. C. Whittow. 1984. Introduction. Pages $1-32$ in G. C. Whittow and H. Rahn, editors. Seabird energetics. Plenum, New York, New York, USA.

Ricklefs, R. E. 1974. Energetics of reproduction in birds. Pages 152-297 in R. A. Paynter, Jr., editor. Avian energetics. Nuttall Ornithological Club, Cambridge, Massachusetts, USA.

Ricklefs, R. E., D. D. Roby, and J. B. Williams. 1986. Daily energy expenditure of adult Leach's Storm-Petrels during the nesting cycle. Physiological Zoology 59:649-660. 
$\rightarrow$ Ricklefs, R. E., S. C. White, and J. Cullen. 1980. Energetics of postnatal growth in Leach's Storm-Petrel. Auk 97:566575.

Schaffner, F. C. 1990. Food provisioning by White-tailed Tropicbirds: effects on the developmental pattern of chicks. Ecology 71:375-390.

Schneider, D. C. 1989. Identifying the spatial scale of density-dependent interaction of predators with schooling fish in the southern Labrador Current. Journal of Fish Biology 35:109-115.

Schneider, D. C., and G. L. Hunt, Jr. 1984. A comparison of seabird diets and foraging distribution around the Pribilof Islands, Alaska. Pages 86-95 in D. N. Nettleship, G. A. Sanger, and P. F. Springer, editors. Marine birds: their feeding ecology and commercial fisheries relationships. Supply and Services Canada, Ottawa, Ontario, Canada.

Sklepkovych, B. O., and W. A. Montevecchi. 1989. The world's largest known nesting colony of Leach's StormPetrels on Baccalieu Island, Newfoundland. American Birds 43:38-42.

Springer, A. M. 1991. Seabird relationships to food webs and the physical environment: examples from the North Pacific. Pages 39-48 in W. A. Montevecchi and A. J. Gaston, editors. Studies of high-latitude seabirds. 1. Behavioural, energetic and oceanographic aspects of seabird feeding ecology. Occassional Paper of the Canadian Wildlife Service Number 68.

Stearns, S. C. 1977. The evolution of life history traits: a critique of the theory and a review of the data. Annual Review of Ecology and Systematics 8:145-171.
Steele, D. S., J. Green, and J. Carter. 1979. A biological and oceanographic study of the Atlantic Southeast Coast Marine Region. Parks Canada Report, Ottawa, Ontario, Canada.

Taylor, J. R. E., and M. Konarzewski. 1989. On the importance of fat reserves for the Little Auk (Alle alle) chicks. Oecologia (Berlin) 81:551-558.

Wanless, S., M. P. Harris, and J. A. Morris. 1985. Radiomonitoring as a method for estimating time budgets for guillemots Uria aalge. Bird Study 32:170-175.

Warham, J., R. Watts, and R. J. Dainty. 1976. The composition of the stomach oils of petrels (Order Procellariiformes). Journal of Experimental Marine Biology and Ecology 23:1-13.

Webster, M. D., and W. W. Weathers. 1988. Effect of wind and air temperature on metabolic rate in Verdins, Auriparus flaviceps. Physiological Zoology 161:543-554.

Weins, J. A. 1984. Modelling the energy requirements of seabird populations. Pages 255-284 in G. C. Whittow and H. Rahn, editors. Seabird energetics. Plenum, New York, New York, USA.

Wood, R. A., K. A. Nagy, N. S. MacDonald, S. T. Wakakuwa, R. J. Beckman, and H. Kaaz. 1975. Determination of oxygen-18 in water contained in biological samples by charged particle activation. Analytical Chemistry 47:646650 . 